\title{
Promoting infomobility services for public transport through ITS
}

\author{
Z. Švédová, M. Ščerba \& M. Bambušek \\ Centrum dopravního výzkumu, Czech Republic
}

\begin{abstract}
Cities have been driving human development for thousands of years and they remain at the heart of our economy today. Given that today more than half of the population lives in cities, it is necessary to continuously improve the services offered to transport and proceed in the deployment of ICT systems. It is necessary that the passenger is increasingly seen as a key partner and that the services offered is continuously improved. The passenger is still just a human and so his requirements are different. It is therefore essential to continue research that is aimed at determining the real demand for services and classification of different types of passengers and their requirements and to quantify them. The paper aims to present a concept of an infomobility plan. The general objective of the infomobility plan is to improve the coordination in promoting, planning and operating ICT in public transport to provide better promotion of policies that foster co-modality through the use of ICT
\end{abstract}

Keywords: infomobility, information systems, public transport, infomobility plan.

\section{Introduction}

Congestions in European cities and metropolitan areas have already reached the point that can be no more considered a step in sustainable development [1].

Citizens' mobility requirements are ever increasing; road traffic volume therefore also expands, as it is related to economic growth. These factors present prime causes for increasing overexertion of the road infrastructure, growing energy consumption and many social, demographic and environmental problems.

European cities are different in many aspects but they face similar challenges and search for common solutions to implement mobility policies. Application of 
information and communication technologies (ICT) and platforms constitutes recent trends. The last ten years have seen a massive involvement of intelligent transportation systems in dealing with mobility issues in urban areas all over Europe [2]. Realized investment to technologies did not bring solutions to all the specified objectives and to the specified extent. The objectives were as follows: simplification of people and goods mobility; accessibility of travel information to citizens; reduction of transportation's environmental impact; a shift toward ecological modes such as public transport. It shows that there are many reasons for this, the most prominent of which are missing plans and strategies for information systems' implementation that would focus on interoperability.

These very aspects provided an impulse for the creation of a research consortium of the POLITE project (Policy Learning in Information Technologies for Public Transport Enhancement), which is funded by the Intereg IVC, EU financial programme, which supports exchange of experience between different regions in Europe.

The paper further focuses on a proposal of the infomobility policy plan content in greater detail and explains the procedures necessary for its creation.

\section{POLITE project}

It is necessary to define the general objectives of Intereg IVC programme at the very beginning to clarify the context of sources of input information for analyses and the possible impact of the results on practical application.

The programme's principle is to initiate and maintain cooperation among European regions [3]. Each region creates its own conception and accepts regional development policy. Nevertheless, their efficiency can be increased through exchange of the experiences that other regions have gained while implementing their policies. Figuratively speaking, the programme is designed for those who do not want to 'invent the wheel' and who search for the inspiration for handling their own problems from European neighbours. The POLITE project focuses on exchange of best practices in the field of infomobility in public transport that contributes to the improvement in sustainable development of European transport and to the reduction of environmental impact in urban areas. Multiple institutions including academic and research establishments and local authorities participate in the project. The project is coordinated by the Calabria Regional Administration (IT) and involves Reading Borough Council (UK), Province of Ferrara (IT), Transport Research Centre (CDV) (CZ), Latvian Transport Development and Education Association (LaTDEA) (LV), Institute of Logistics and Warehousing (ILIM) (PL) and Polis (BE).

\subsection{Infomobility}

One of the project's objectives was to study the current state of infomobility in European countries and to propose actions designed to reduce and close any competitiveness gap by means of best practices. One of the ways to improve 
public transport organization is to identify, communicate and facilitate the transfer of practices that seem to work successfully somewhere else.

The meaning of the term 'infomobility' is given as follows.

Infomobility refers to procedures, systems and devices based on Intelligent Transport Systems and Services (ITS) that improve the mobility of persons and goods by collecting, processing and distributing information. Infomobility applications can be used both by the mobility operators and by the final users for all modes of transport [4].

\subsection{Methodology}

During the first year of POLITE, the project partners finalized the definition of the infomobility measures and policies that they intend to share as well as to see implemented in their sites. This was done in a process consisting of mapping the experience of the partners, followed by mapping of their future plans, i.e. measures on which they will be working in the next couple of years. Ten groups of public infomobility related measures/policies have been identified.

As the first step, each partner highlighted the topics for his regional development activities in infomobility in public transport, both the existing experience and future plans. The gathered topics were analysed and then organised into groups of elementary measures with 54 specific sub-measures that were also finalized into groups to describe each measure.

Based on this list of elementary measures, an Excel chart was developed as a tool for the description of the sub-measures and for the preparation of the questionnaire.

\subsection{Infomobility policies measures}

Although each of the city policies might have its vision, it is necessary to evaluate the current state and to define the gaps that we set to correct and that become crucial for the construction of the infomobility plan this way in order to have a really efficient infomobility policy vision.

Individual cities can set their own priorities based on the proposed measures and identification tools. Elementary measure groups are listed in Table 1.

Table 1: Elementary measure groups.

\begin{tabular}{|l|l|l|}
\hline $\begin{array}{l}\text { PT legislation and } \\
\text { regulation }\end{array}$ & $\begin{array}{l}\text { ITS technical } \\
\text { standardization for } \\
\text { interoperability }\end{array}$ & $\begin{array}{l}\text { Modelling tools and } \\
\text { measures }\end{array}$ \\
\hline $\begin{array}{l}\text { PT reorganization } \\
\text { into multimodal } \\
\text { system }\end{array}$ & $\begin{array}{l}\text { Infrastructural } \\
\text { measures }\end{array}$ & PT information measures \\
\hline $\begin{array}{l}\text { Cooperation among } \\
\text { administrations }\end{array}$ & Innovative ICT for PT & Advanced PT ticketing \\
\hline
\end{tabular}


Figure 1 depicts a percentual comparison of individual elementary measure types according to their preference as a priority measure. The chart makes it clear that measure no. 2 is considered to have the highest priority.

Figure 2 shows a comparison of what measures are considered priority for practical implementation and what measures create part of recent best practices.

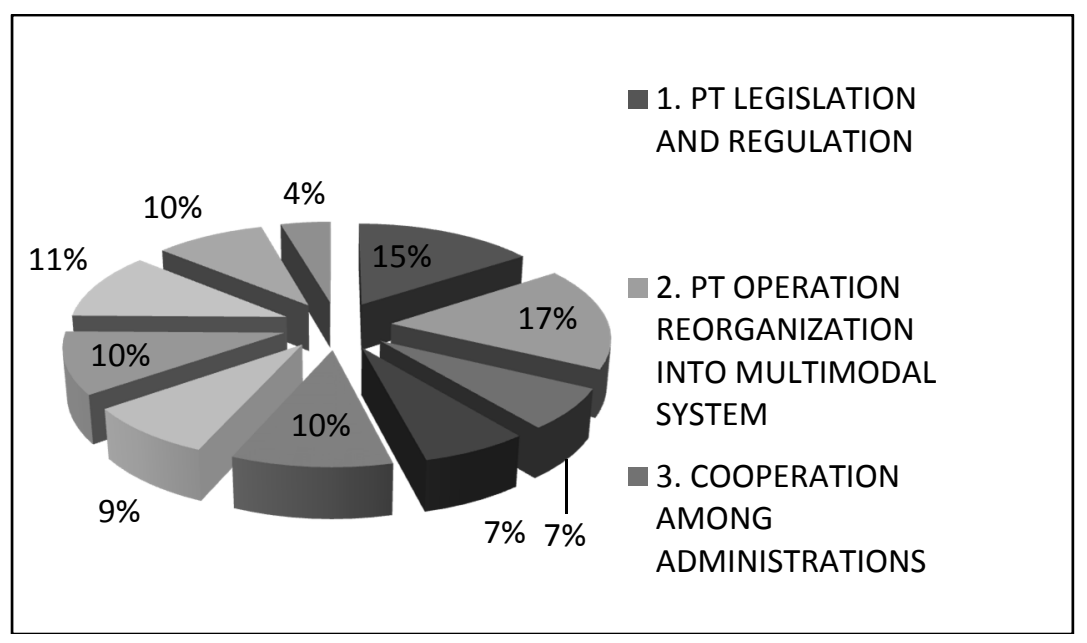

Figure 1: Frequency of the type of measures [4].

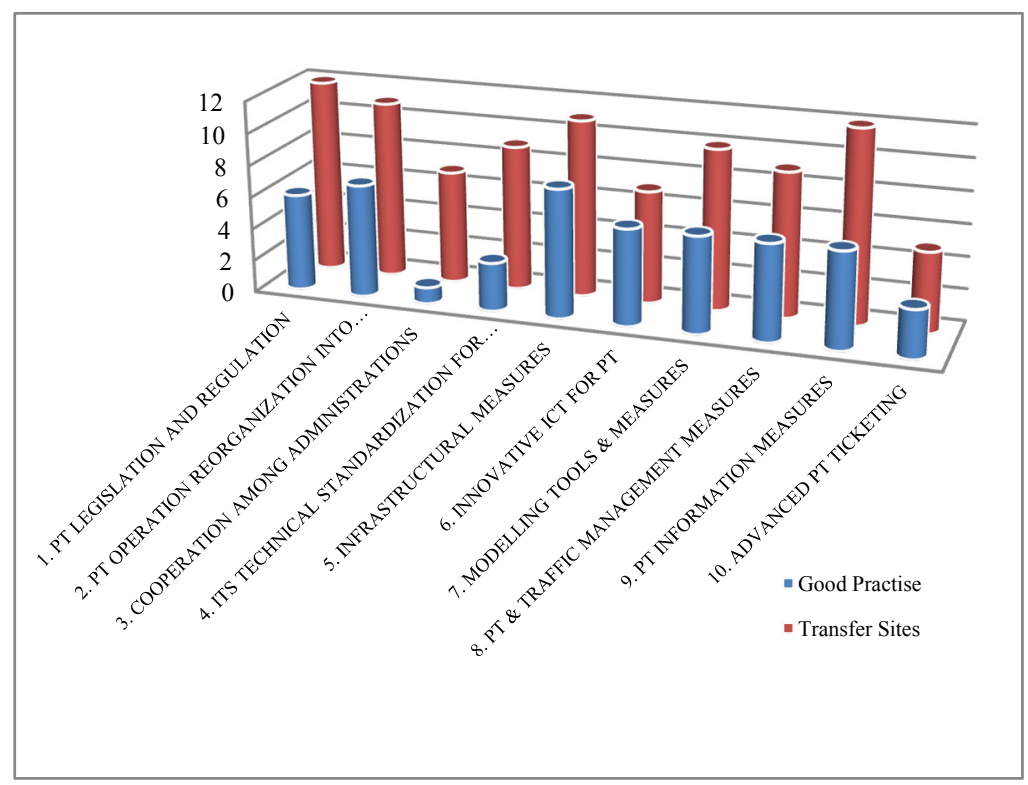

Figure 2: Frequency of the types of measures [4]. 
As you can see from the chart, the measures related to information systems in public transport have the highest assessment. Conversely, the measure related to public transport ticketing is assessed as the least. That also confirms that, recently, importance is put on acquiring both static and real-time information in public transport.

\subsection{Good practices}

The importance of a possibility to evaluate the transport system and to locate the gaps in the process of the plan design and its implementation proves to be a priority.

The POLITE project defined and analysed 32 good practices from several EU states in order to enable determination of these gaps and to compare those systems.

Comparative analysis of good practices and choice of the best practice enabled the application of a multi-criteria comparative analysis.

Table 2 lists selected examples.

The measures listed in Table 3 are considered for the best practices analysis.

\subsubsection{Comparative analysis of good practices and choice of the best one for each group of good practices}

The multi-criteria analysis method has been chosen for comparison of individual good practices and selection of the best one. It is the so-called Saaty method [6] of criteria weights determination and it can be divided into two steps. In the first step, preference relations of criteria pairs are determined, that takes place in the table in whose columns and rows the criteria are indicated in the same order. Besides criteria pairs' preference direction, intensity of this preference is also assessed, which is expressed by certain amount of points from a chosen point scale.

The first step is analogical to the pairwise comparison method - again, the assessment of preference relations of criteria pairs arranged in a table takes place. Contrary to the pairwise comparison method, intensity of this preference, to be is expressed by certain amount of points from a chosen point scale, is also assessed besides criteria pairs' preference direction.

To perform the calculations of criteria, the commonly used pairwise comparison scale 1-9 [5].

This scale has the following weights $\mathrm{W} 1$ and $\mathrm{W} 2$ : for two alternatives $\mathrm{A} 1$ and A2:

$\mathrm{W} 1=1 ; \mathrm{W} 2=1$, if two alternatives $\mathrm{A} 1$ and $\mathrm{A} 2$ are equal in importance;

$\mathrm{W} 1=3 ; \mathrm{W} 2=1 / 3$, if $\mathrm{A} 1$ is slightly more important than $\mathrm{A} 2$;

$\mathrm{W} 1=5 ; \mathrm{W} 2=1 / 5$, if $\mathrm{A} 1$ is strongly more important than $\mathrm{A} 2$;

$\mathrm{W} 1=7 ; \mathrm{W} 2=1 / 7$, if $\mathrm{A} 1$ is very strongly more important than $\mathrm{A} 2$;

$\mathrm{W} 1=9$; $\mathrm{W} 2=1 / 9$, if $\mathrm{A} 1$ is absolutely more important than $\mathrm{A} 2$;

$2,4,6$, and 8 are intermediate values between the two adjacent judgments. 
Table 2: $\quad$ Selected GP.

\begin{tabular}{|c|c|}
\hline ID & Practice \\
\hline 1 & $\begin{array}{l}\text { Traffic monitoring and management: Floating Car Data (FCD) as } \\
\text { traffic sensors. Result of S.I.MO.NE Project/Torino Italy }\end{array}$ \\
\hline 2 & $\begin{array}{l}\text { Stimer/Mi Muovo Project - Mobility Integrated Fare System in RER } \\
\text { (Emilia-Romagna Region) - buses, trains and bike sharing }\end{array}$ \\
\hline 3 & $\begin{array}{l}\text { Multi-channel information system on mobility at regional scale/ } \\
\text { Campania/Italy }\end{array}$ \\
\hline 4 & Sustainable Mobility Plan (SMP)/Santander/Spain \\
\hline 6 & Traffic Management/Verona/Italy \\
\hline 7 & $\begin{array}{l}\text { Intermodal infomobility platform and sms } \\
\text { ticketing/Genova/Liguria/Italy }\end{array}$ \\
\hline 8 & Traffic management during big events/Perugia/Italy \\
\hline 9 & SMS ticketing system of public transport operator/Flanders/Belgium \\
\hline 10 & Mobility and traffic management in firms/Vlajevo/Serbia \\
\hline 11 & Open public transport data/London/UK \\
\hline 12 & $\begin{array}{l}\text { Real time passenger information system, bus priority at signals, public } \\
\text { transport mobile apps, city access control. smart card/Cambridgeshire } \\
\text { County Council/UK }\end{array}$ \\
\hline 13 & Bus lane enforcement/Greater Bristol/UK \\
\hline 14 & $\begin{array}{l}\text { Real time information system and bus priority at signals/Greater } \\
\text { Bristol/UK }\end{array}$ \\
\hline 15 & $\begin{array}{l}\text { Real time passenger information system, bus priority at signals, } \\
\text { disability accessibility/City and County of Swansea/UK }\end{array}$ \\
\hline 16 & Mobile travel information/Aalborg/Denmark \\
\hline 17 & On-board bus travel information/Aalborg/Denmark \\
\hline 18 & Real Time Passenger Information System (Mezi)/Bern/Switzerland \\
\hline 19 & Demand responsive transport (Tele-bus)/Kraków/Poland \\
\hline 20 & Advanced PT ticketing (Skycash) \\
\hline 21 & Multimodal journey planner for the Czech Republic/Poland \\
\hline 22 & $\begin{array}{l}\text { Integrated public transport system and smart ticketing/Ostrava and } \\
\text { Silesian-Moravian region/Czech Republic }\end{array}$ \\
\hline 23 & $\begin{array}{l}\text { Public transport dispatching under KORDIS integrator/organizer: } \\
\text { CED/Brno and South Moravian region/Czech Republic }\end{array}$ \\
\hline 24 & $\begin{array}{l}\text { Real Time Passenger Information System/Central Bohemia } \\
\text { region/Czech Republic }\end{array}$ \\
\hline 25 & $\begin{array}{l}\text { Multimodal integrated transport/Prague and Central Bohemia } \\
\text { region/Czech Republic }\end{array}$ \\
\hline 26 & Unified intermodal cargo service/Rigas region/Latvia \\
\hline 27 & Interchange Principe Pio/Madrid/Spain \\
\hline 28 & Integrated system of selling and reserving tickets/Riga/Latvia \\
\hline 29 & Atlas Public Transport Ticketing System in Riga \\
\hline 30 & Interactive passenger service in train traffic/Rigas region/Latvia \\
\hline 31 & Premier Route Bus Corridor Network/UK \\
\hline 32 & GIM/Valijevo \\
\hline
\end{tabular}


The importance of the criteria is evident from the evaluation of the priority vector.

The good practices' measures used in criteria of efficiency are distributed into four groups. The created hierarchical structure of the criteria is shown in Table 3.

Table 3: Hierarchical structure of the criteria (indices of measures).

\begin{tabular}{|l|l|l|l|}
\hline $\begin{array}{l}\text { 1. Organisation } \\
\text { and Legislation }\end{array}$ & $\begin{array}{l}\text { 2. Infrastructural } \\
\text { Action }\end{array}$ & $\begin{array}{l}\text { 3. Information } \\
\text { Action }\end{array}$ & 4. Modelling \\
\hline $\begin{array}{l}\text { PT Legislation } \\
\text { and regulation }\end{array}$ & $\begin{array}{l}\text { ITS technical } \\
\text { standardization }\end{array}$ & $\begin{array}{l}\text { Pt traffic } \\
\text { management } \\
\text { measures }\end{array}$ & $\begin{array}{l}\text { Modelling tools } \\
\text { and measures }\end{array}$ \\
\hline $\begin{array}{l}\text { PT } \\
\text { reorganization } \\
\text { into multimodal } \\
\text { system }\end{array}$ & $\begin{array}{l}\text { Infrastructural } \\
\text { measures }\end{array}$ & $\begin{array}{l}\text { Pt information } \\
\text { measures }\end{array}$ & \\
\hline $\begin{array}{l}\text { 1. Organisation } \\
\text { and Legislation }\end{array}$ & $\begin{array}{l}\text { 2. Infrastructural } \\
\text { Action }\end{array}$ & $\begin{array}{l}\text { 3. Information } \\
\text { Action }\end{array}$ & 4. Modelling \\
\hline $\begin{array}{l}\text { Cooperation } \\
\text { among } \\
\text { administration }\end{array}$ & $\begin{array}{l}\text { Innovative ICT } \\
\text { for PT }\end{array}$ & $\begin{array}{l}\text { Advance PT } \\
\text { ticketing }\end{array}$ & \\
\hline
\end{tabular}

The paired comparison of good practices with numbers $i$ and $j$ for the measure with number $\mathrm{k}$ is determined by index:

$$
\delta_{K}=P_{K}^{(i)}-P_{K}^{(j)}
$$

The values of paired comparison criterion are determined for the scale 1-9 using the value of index $\delta_{K}$.

Using paired comparison matrices and results of vector $\mathrm{P}=\left(P_{1}, P_{2}, . P_{k}, P_{10}\right)$, the vectors of measures' priorities for each group of measures should be calculated.

These vectors should be used for global vector of GP priorities calculation [5].

\section{Execution of the plan creation}

\subsection{Preliminary phase}

In the first step, it is necessary to answer elementary questions prior to building future development plans.

- What factors are critical for creation of a new system?

- How to apply the principles defined in the action plans. 
- How is development of new systems influenced by the European Commission requirements?

- $\quad$ Are there any independent technical documents for suppliers to rely on while assigning public tenders?

- Where to search for professional help with application of recent ITS standards for public transport.

- Are there any rules/regulations/standards with direct impact on system formation being created?

Moreover, it is necessary to take into the account the fact that by introduction of innovative technologies, we enable an increase of service levels primarily in the areas listed as reasons for possible change of travel behaviour - especially the shift from individual to public transport. These reasons and areas are considered primarily:

- Increasing reliability of public transport system - long-run and in-depth analysis of chronic delays or early arrivals can provide efficient regulation of timetables; it also allows for taking strategic transport measures that enable more fluent transportation in general (e.g. better adjustment of control plans, construction of ring roads, bottleneck detection, etc.). It is also possible to gradually eliminate the phenomena related to failing connections etc. by means of analysis.

- Increase of passengers' awareness - with a proper set of regulations and standards, it is possible to attain the state with complex real-time vehicle traffic data available on a single platform. This information can be provided to passengers while planning their route or even during travel. Newly emerging applications will make it possible to suggest alternative connections during unexpected events, etc.

- Facilitation of transfers - up-to-date information on vehicle traffic will be always available when using connection transfer and, also, applications will guide passengers through an unknown environment in the near future.

- Improved equipment of terminals and stop points - awareness of passenger movement and of utilization of individual stops or terminals will allow investors to constantly improve the environment of waiting areas that are to be equipped with modern technologies, such as Internet connection, electronic displays to inform about current delay of individual connections or about surroundings of a stop or terminal (shops, cafés, food, etc).

\subsection{Individual infomobility areas}

One of the ways to create a plan that will really cover an infomobility area in public transport is to define priority actions for separate subgroups.

These subgroups are:

- $\quad$ Public Transport/Multimodal Information Systems.

- $\quad$ Public Transport Fleet Management Systems.

- Public Transport Interchanges. 
- $\quad$ Public Transport Priority Systems.

- $\quad$ Public Transport Payment Systems.

The conducted multi-criteria analysis has assessed good practices and specified those that are suitable to be mentioned as proven examples for practical implementation in individual subgroups. These selected examples can be used as templates for determining future development, as well as templates for creating an action plan of infomobility development in a given area.

\subsubsection{Examples for practical implementation}

The results of comparative assessment of good practices are the following [5].

Table 4: Practices that have the highest values of global priority vectors in the GP groups.

\begin{tabular}{|l|l|l|}
\hline Name of group & Good practice & City/region/country \\
\hline $\begin{array}{l}\text { Public Transport/ } \\
\text { Inftimodal } \\
\text { Systems }\end{array}$ & $\begin{array}{l}\text { No. 24 Real time } \\
\text { passenger information } \\
\text { system }\end{array}$ & $\begin{array}{l}\text { Prague/Czech } \\
\text { Republic }\end{array}$ \\
\hline Name of group & Good practice & City/Region/Country \\
\hline $\begin{array}{l}\text { Public Transport } \\
\text { Systems Management }\end{array}$ & $\begin{array}{l}\text { No.4 Sustainable } \\
\text { Mobility Plan (SMP) }\end{array}$ & Santander/Spain \\
\hline $\begin{array}{l}\text { Public Transport } \\
\text { Interchanges }\end{array}$ & $\begin{array}{l}\text { No. 25 Multimodal } \\
\text { Integrated Transport }\end{array}$ & $\begin{array}{l}\text { Prague and Central } \\
\text { Bohemia region/ } \\
\text { Czech Republic }\end{array}$ \\
\hline $\begin{array}{l}\text { Public Transport } \\
\text { Priority Systems }\end{array}$ & $\begin{array}{l}\text { No.15 Real Time } \\
\text { Passenger } \\
\text { Information System, } \\
\text { bus priority at signals, } \\
\text { disability accessibility }\end{array}$ & $\begin{array}{l}\text { City and County of } \\
\text { Swansea/UK }\end{array}$ \\
\hline $\begin{array}{l}\text { Public Transport } \\
\text { Payment Systems }\end{array}$ & $\begin{array}{l}\text { No. 22 Integrated } \\
\text { public transport } \\
\text { system and smart } \\
\text { ticketing }\end{array}$ & $\begin{array}{l}\text { Ostrava and } \\
\text { Silesian-Moravian } \\
\text { region/Czech } \\
\text { Republic }\end{array}$ \\
\hline
\end{tabular}

\subsection{Processing requirements for infomobility plan compilation}

The plan will be designed as an integrated social, technical and economical process that includes development directions and tasks in the extent proportionally corresponding to expected available funds as well as the tasks of a non-financial nature - as already mentioned, these include processes of policy support, legislation, standardization, certification and organization. 
In order to evaluate the current state, it is possible to use the set criteria listed in Table 4.

The next step is to prepare the infomobility plan in harmony with the SUMP plan.

\section{Conclusion}

The implementation phase starts after approval of the plan. The infomobility plan, as a strategic document, provides a framework for those activities but does not specify in detail how to implement the measures. It is necessary to point out that the implementation process also has to follow the structured approach in order to improve the objectives and to plan, in elaborate detail, control, report and monitor implementation of the measures. These cycles are much shorter than the planning cycle and they have to be flexible enough to adapt to new situations.

\section{References}

[1] Ambrosino, N., 2012. Infomobility Systems and Sustainable Transport Services. Rome: Italian National Agency for New Technologies, Energy and the Sustainable Economic Development.

[2] European Commission, Action Plan for the Deployment of Intelligent Transport Systems in Europe [COM(2008)886], http://ec.europa.eu /transport/its/, 2008

[3] Intereg IVC. http://www.interreg4c.eu/

[4] POLITE project, 2012. Report "Definition of Infomobility policy themes for exchange".

[5] POLITE project, 2012. Activity 3.2B Report "Analysis and reporting on best practices".

[6] Saaty T.L (2001) Decision Making for Leaders: The Analytic Hierarchy Process for Decisions in a Complex World, New Edition 2001 (Analytic Hierarchy Process Series, Vol. 2), RWS Publications. 